\title{
Intravesical migration of intrauterine device
}

\author{
Taro Shimizu, ${ }^{1}$ Yasuharu Tokuda ${ }^{2}$
}

${ }^{1}$ Rollins School of Public Health, Emory University, Atlanta, Georgia, USA

${ }^{2}$ Department of General Internal Medicine, Tsukuba University, Mito, Ibaraki, Japan

\section{Correspondence to} Dr Taro Shimizu, shimizutaro7@gmail.com

\section{DESCRIPTION}

A 90-year-old woman, with dementia, presented with fever and shaking chill. She was diagnosed as sepsis by urinary tract infection (UTI). She was admitted to the intensive care unit. Despite aggressive hydration care and antibiotics treatment, she finally died. Additional history revealed she had multiple UTI over 50 years.

An autopsy revealed that a round-shape, a metal plate with a diameter of $5 \mathrm{~cm}$ was completely immersed in the centre of the posterior wall of the urinary bladder with stone formation (figures 1 and 2). The plate turned out to be an intrauterine device which was inserted in 1951, 61 years back.

Although perforation of the uterus by an intrauterine device is common, intravesical migration with secondary stone formation is an extremely rare complication. ${ }^{1}$ In this patient, the migration was suspected by CT scan, but she and her family declined any additional invasive investigation. The migrated device was detected by autopsy.

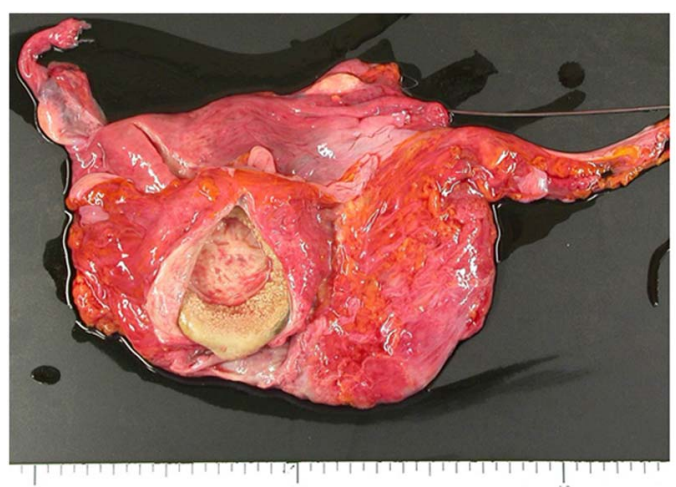

Figure 1 An autopsy revealed an intrauterine device which was completely immersed in the centre of the posterior wall of the urinary bladder with stone formation.

\section{Learning points}

To cite: Shimizu T, Tokuda Y. BMJ Case Reports Published online: [please include Day Month Year] doi:10.1136/bcr-2012008127
Intravesical migration of intrauterine devices can occur.

- If a patient has a recurrent UTI, chronic obstruction of the urinary tract should be ruled out until proven otherwise.

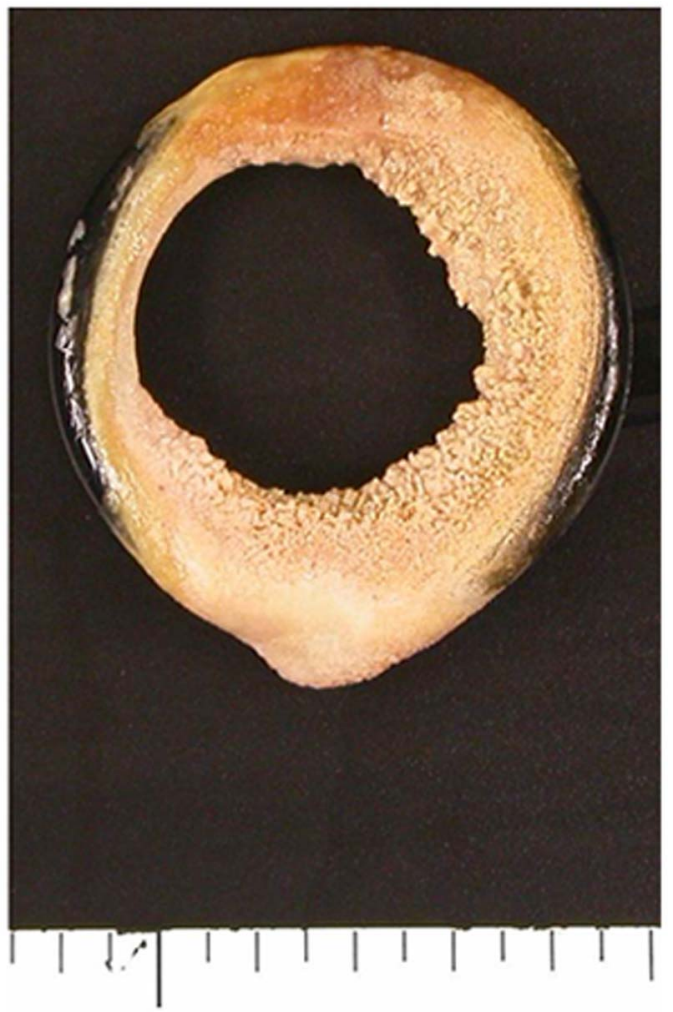

Figure 2 A round-shape metal plate with a diameter of $5 \mathrm{cms}$ with stone formation.

Competing interests None.

Patient consent Obtained.

Provenance and peer review Not commissioned; externally peer reviewed.

\section{REFERENCE}

1 Tosun $\mathrm{M}$, Celik H, Yavuz E, et al. Intravesical migration of an intrauterine device detected in a pregnant woman. Can Urol Assoc J 2010;4:E141-3. 


\section{Images in...}

Copyright 2013 BMJ Publishing Group. All rights reserved. For permission to reuse any of this content visit http://group.bmj.com/group/rights-licensing/permissions.

BMJ Case Report Fellows may re-use this article for personal use and teaching without any further permission.

Become a Fellow of BMJ Case Reports today and you can:

- Submit as many cases as you like

- Enjoy fast sympathetic peer review and rapid publication of accepted articles

- Access all the published articles

- Re-use any of the published material for personal use and teaching without further permission

For information on Institutional Fellowships contact consortiasales@bmjgroup.com

Visit casereports.bmj.com for more articles like this and to become a Fellow 